\title{
Effects of Regulation and Technology on End Uses of Nonfuel Mineral Commodities in the United States
}

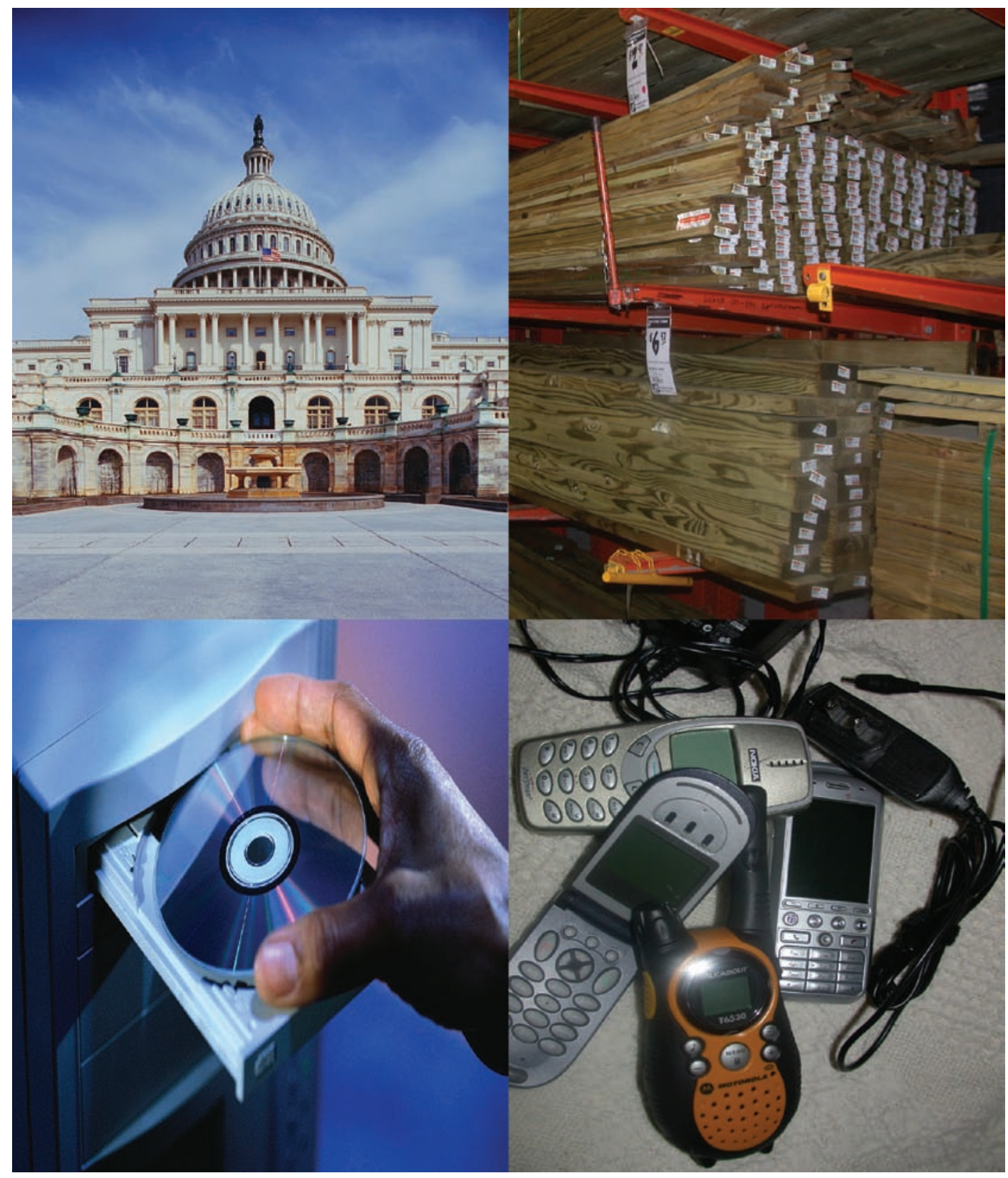

Scientific Investigations Report 2006-5194 
Cover photographs. U.S. Capitol and compact disks, courtesy of Microsoft Corporation; lumber and cell phones, courtesy of Michael R. Sanio. 


\section{Effects of Regulation and Technology on End Uses of Nonfuel Mineral Commodities in the United States}

By Grecia R. Matos

Scientific Investigations Report 2006-5194 


\title{
U.S. Department of the Interior DIRK KEMPTHORNE, Secretary
}

\author{
U.S. Geological Survey \\ Mark D. Myers, Director
}

\section{U.S. Geological Survey, Reston, Virginia: 2007}

For product and ordering information:

World Wide Web: http://www.usgs.gov/pubprod

Telephone: 1-888-ASK-USGS

For more information on the USGS — the Federal source for science about the Earth, its natural and living resources, natural hazards, and the environment:

World Wide Web: http://www.usgs.gov

Telephone: 1-888-ASK-USGS

Any use of trade, product, or firm names is for descriptive purposes only and does not imply endorsement by the U.S. Government.

Although this report is in the public domain, permission must be secured from the individual copyright owners to reproduce any copyrighted materials contained within this report.

Suggested citation:

Matos, G.R., 2007, Effects of regulation and technology on end uses of nonfuel mineral commodities in the United States: U.S. Geological Survey Scientific Investigations Report 2006-5194, 15 p. 


\section{Contents}

Abstract
Introduction
Methods.
Overview of Materials Flow
Shifts in End Uses of Mineral Commodities Owing to Regulation
Arsenic
Asbestos
Shifts in End Uses of Mineral Commodities Owing to Changing Technologies
$\quad$ Germanium
Indium
Strontium
Summary.
References Cited

\section{Figures}

1. Flowchart showing mineral materials flow cycle .........................................................

2-10. Graphs showing-

2. Raw, nonfuel mineral materials put into use annually from 1900 through 2003 in the United States...........................................................

3. Arsenic end uses from 1975 through 2003 in the United States.................................

4. Asbestos end uses from 1975 through 2003 in the United States...............................5

5. Lead end uses from 1975 through 2003 in the United States......................................6

6. Mercury end uses from 1975 through 2002 in the United States ...............................

7. Gallium end uses from 1975 through 2003 in the United States ................................

8. Germanium end uses from 1975 through 2003 in the United States........................10

9. Indium end uses from 1975 through 2003 in the United States ...............................11

10. Strontium end uses from 1975 through 2003 in the United States ..........................12 



\title{
Effects of Regulation and Technology on End Uses of Nonfuel Mineral Commodities in the United States
}

\author{
By Grecia R. Matos
}

\section{Abstract}

The regulatory system and advancement of technologies have shaped the end-use patterns of nonfuel minerals used in the United States. These factors affected the quantities and types of materials used by society. Environmental concerns and awareness of possible negative effects on public health prompted numerous regulations that have dramatically altered the use of commodities like arsenic, asbestos, lead, and mercury. While the selected commodities represent only a small portion of overall U.S. materials use, they have the potential for harmful effects on human health or the environment, which other commodities, like construction aggregates, do not normally have.

The advancement of technology allowed for new uses of mineral materials in products like high-performance computers, telecommunications equipment, plasma and liquid-crystal display televisions and computer monitors, mobile telephones, and electronic devices, which have become mainstream products. These technologies altered the end-use pattern of mineral commodities like gallium, germanium, indium, and strontium. Human ingenuity and people's demand for different and creative services increase the demand for new materials and industries while shifting the pattern of use of mineral commodities.

The mineral commodities' end-use data are critical for the understanding of the magnitude and character of these flows, assessing their impact on the environment, and providing an early warning of potential problems in waste management of products containing these commodities. The knowledge of final disposition of the mineral commodity allows better decisions as to how regulation should be tailored.

\section{Introduction}

The U.S. Geological Survey (USGS) provides information to policy makers and the public concerning the use and flow of nonfuel minerals and mineral materials in the United States economy. The USGS collects, analyzes, and disseminates minerals information on most nonfuel mineral commodities. As part of this endeavor, the USGS developed a compilation of historical statistics for mineral and material commodities in the United States (Kelly and Matos, 2005). Analysis of the data contained in this study reveals changes in end-use patterns for selected commodities that result from numerous factors. Two of these factors, regulation and the development of new technologies, are analyzed for eight nonfuel mineral commodities for the period 1975 to 2003.

\section{Methods}

For most mineral commodities, end-use data are based on surveys of U.S. industry by the USGS and are published in the USGS Minerals Yearbook (MYB). For several mineral commodities, the end-use data are not available or are of limited reliability. In such cases, data usually are calculated by applying estimated end-use shares (percentages) by category, as reported in the annual USGS Mineral Commodity Summaries (MCS), to apparent consumption estimates. For some other mineral commodities, USGS mineral-commodity specialists estimate end-use statistics using a variety of sources of information. For a limited number of commodities, no end-use data are available. More information about the USGS nonfuel mineral survey methods is available in Busse (2004).

End-use statistics are considered only an estimate for how a mineral commodity has been used in the U.S. economy. Ideally, the sum of end uses should equal estimated apparent consumption and, therefore, provide a full accounting. However, this is not the case for several commodities. Data limitations may result from changes in collection or estimation methodology, the structure or performance of the industry, and industry response to the survey. Because of these changes, use of the "undistributed" and "other" end-use categories has increased over time.

End-use data do not reflect the effects of globalization, nor do they account for mineral materials contained in imports or exports of finished or semi-finished products. For example, imported mercury contained in fluorescent lamps and lead contained in batteries of imported cars are not reflected in the U.S. statistics. Without these data, complete statements cannot be made about U.S. trends in mineral commodity use, substitution of materials by U.S. industry, or the environmental effects of final disposition of mineral materials contained in products. Mineral end uses in the United States are measured at the industrial stage (raw, nonfuel mineral materials) because data on production and trade in primary metal products are easily accessible. 


\section{Overview of Materials Flow}

The materials flow cycle (fig. 1) provides a conceptual overview of the flow of mineral-based materials through the economy and the environment. The cycle begins with the extraction of mineral resources from the environment and from sources available for recycling, remanufacturing, and reuse for primary and secondary production; then the flow of mineral materials proceeds through the fabrication and manufacturing processes. The mineral commodities contained in products provide services in the economy during their useful life, while other materials flow to recycling, remanufacturing, reuse, or disposal.

Throughout the life cycle of a mineral material, the potential for losses and adverse effects on the environment exists through emissions, losses, wastes, or dissipation of materials into the environment. A time of residence for the mineral materials is reflected in the additions to stock and built infrastructure, after which time the material completes its useful time in service. Then, the material either is discarded in landfills as scrap or demolition material, or is recovered for recycling, remanufacturing, or reuse.

Nonfuel mineral materials used in the United States changed substantially in the 20th century. In 1900, each person consumed approximately 1.2 metric tons ( $\mathrm{t}$ ) of metals and minerals; by 2003, the amount had increased to nearly $11 \mathrm{t}$. The quantity of new, raw mineral materials added to the U.S. economy in 1900 was 93 million t, and in 2003, the quantity was about 3.1 billion $t$ (fig. 2). Changes in the quantity and types of mineral materials entering the U.S. economy each year often mirror major economic and political events. Over the first 50 years of the 20th century, the U.S. economy was transformed from a predominately-agricultural economy to an industrial economy. Starting in about 1950, the economy began to move toward a post-industrial or service economy. A detailed analysis of these trends is in Matos and Wagner (1998).

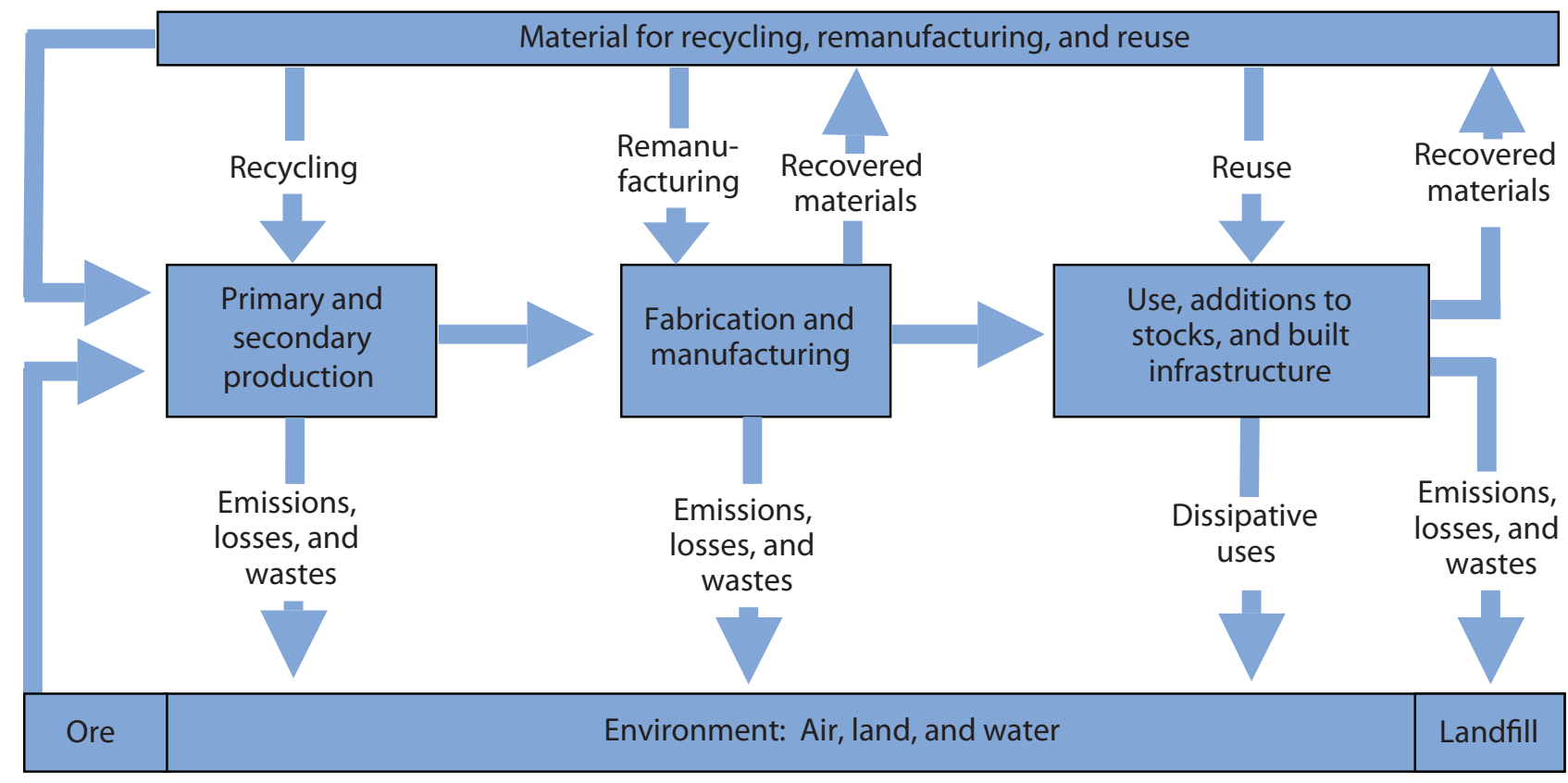

Figure 1. Mineral materials flow cycle. 


\section{Shifts in End Uses of Mineral Commodities Owing to Regulation}

Changes in technology, the quest for substitutes, and the selection of materials for specific products are often the result of industry compliance to regulations issued by Federal, State, or local government departments or agencies. Hence, the end use of a mineral commodity may be constrained or increased directly or indirectly by regulatory actions.

Awareness of the potentially negative environmental effects of some of the mineral commodities, such as arsenic, asbestos, lead, and mercury, on human health and nature has resulted in regulation on the use of these commodities. For example, the use of lead in paints and fuel has been discontinued, and the use of asbestos in thermal insulation has been greatly limited. Examples of how the end-use patterns of particular mineral commodities have been altered by regulation are presented in the following sections. These commodities were selected because government agencies and nongovernmental groups have concerns about their effects on public health and the environment if uncontrolled releases occur, even in small amounts.

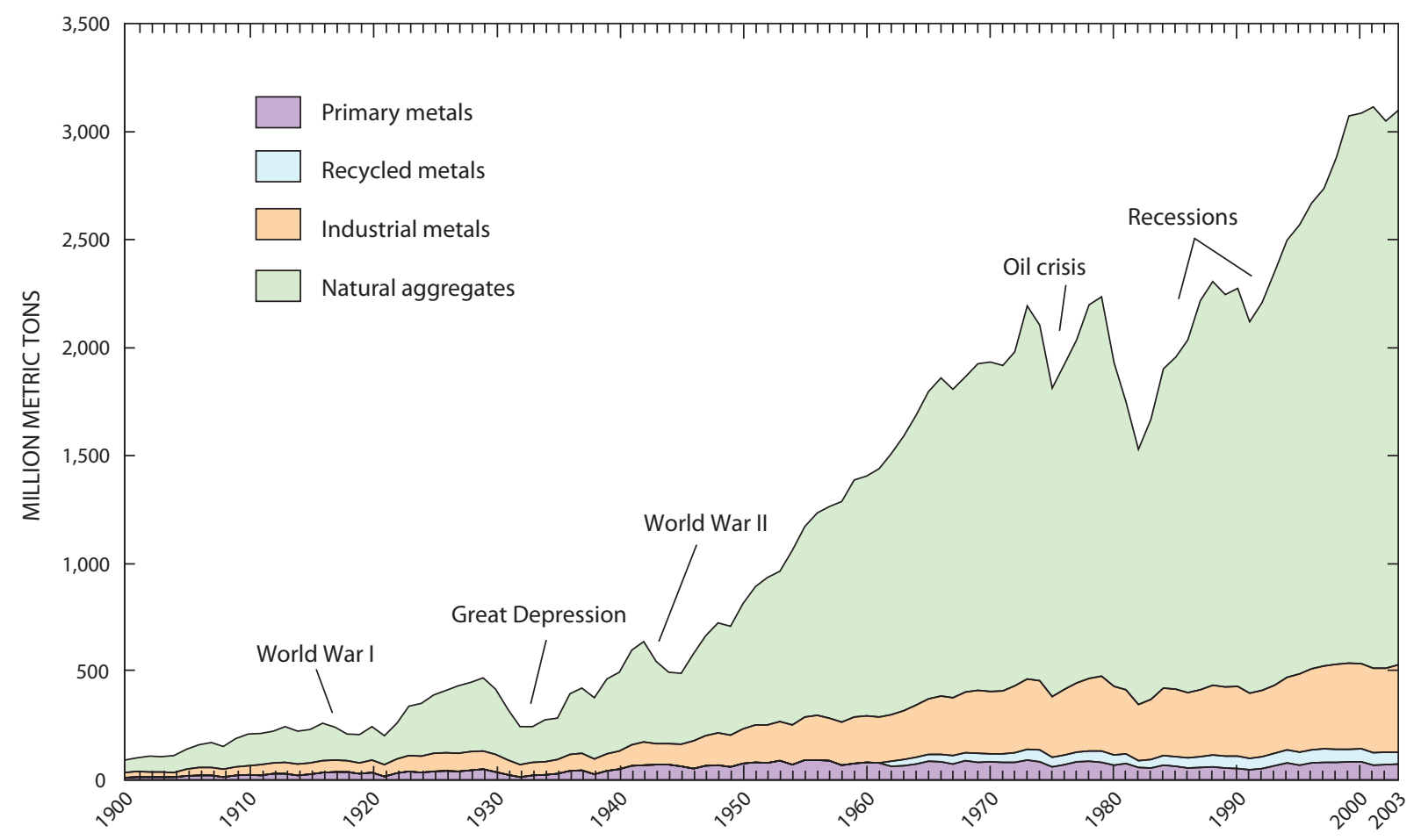

Figure 2. Raw, nonfuel mineral materials put into use annually from 1900 through 2003 in the United States. (Materials embedded in imported goods not included.) 


\section{Arsenic}

Historically, the leading end-use for arsenic in the United States was as a pesticide and fungicide. Arsenic was used as a pesticide or desiccant for crops such as cotton, and as an insecticide on various small fruits and certain vegetable crops. In 1987, the U.S. Environmental Protection Agency (EPA) proposed to cancel registrations of almost all of the non-wood preservative uses of inorganic arsenicals based on concerns of acute toxicity from accidental ingestion by children and of carcinogenicity risk for workers handling inorganic arsenic pesticides. In 1993, the U.S. EPA proposed cancellation of the use of arsenic acid on cotton, and nearly eliminated the use of arsenic in agriculture (fig. 3; Cornell University, 1993; U.S. Interagency Working Group on Industrial Ecology, Materials, and Energy Flows, 1999).

End-use analysis shows that the decline in the use of arsenic in agricultural chemicals was offset by its use as a component of wood preservative, primarily in the form of chromated copper arsenate (CCA). CCA was used in the construction of new homes, outdoor patios and decks, and playgrounds for parks and schools. Arsenic use in pressure-treated wood increased rapidly during the time period under analysis, rising from $700 \mathrm{t}$ in 1975 to approximately 19,200 $\mathrm{t}$ in 2003, and increased from 5 percent of U.S. apparent arsenic consumption in 1975 to about 90 percent in 2003. In 2003, based on consultation with the EPA, the domestic manufacturers of CCA began a voluntary transition from CCA to alternative wood preservatives in most household uses and play areas, which led to a drop in the overall arsenic use from 21,600 $\mathrm{t}$ in 2003 to 6,800 t in 2004 (U.S. Environmental Protection Agency, 2005). Satisfactory alternatives to arsenic-based preservatives now include biocides containing silver (Silver Institute, 2005) and products resulting from new technologies, such as nanotechnology, which enables the incorporation of nanosized particles into the wood as an active preservative (Industrial Minerals, 2005).

Arsenic also is used in nonferrous alloys (such as for bearings, type metals, lead ammunition, and automotive body solder, and it may be added to brass to improve corrosion resistance), and electronic components (such as a variety of semiconductor applications, including solar cells, light emitting diodes, lasers, and integrated circuits) in small quantities. Arsenic oxide is used in glass applications to improve color, transparency, and brilliance.

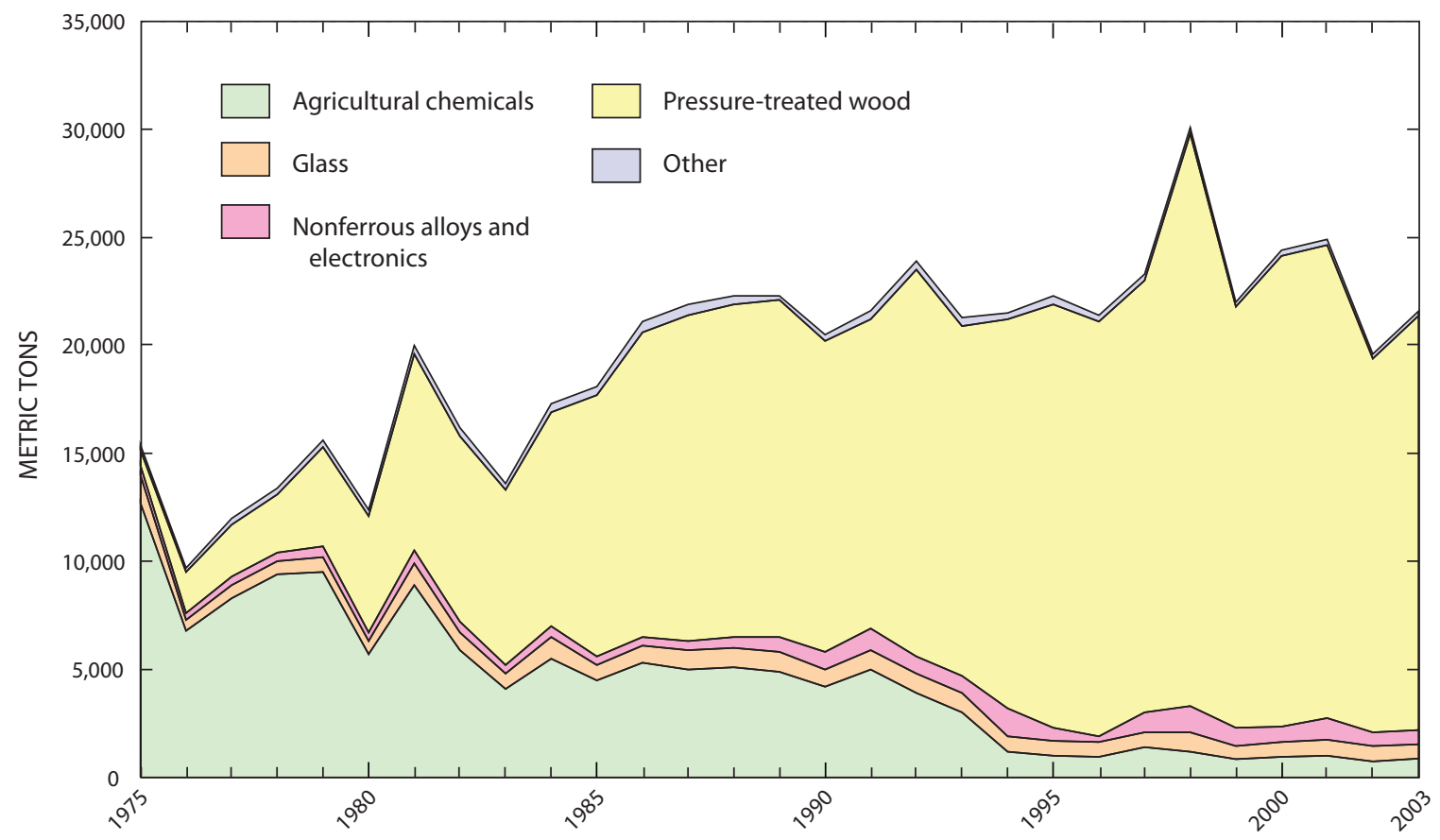

Figure 3. Arsenic end uses from 1975 through 2003 in the United States. 


\section{Asbestos}

Asbestos fibers historically have been used in a variety of industrial applications. Many of these applications have now been abandoned and others are pursued under strictly regulated conditions. The main properties of asbestos fibers that can be exploited in industrial applications led to several main classes of industrial applications such as fire protection and heat or sound insulation, fabrication of papers and felts for flooring and roofing products, pipeline wrapping, thermal and electrical insulation, friction products in brake or clutch pads, asbestos-cement products, reinforcement of plastics, fabrication of packings and gaskets, vinyl or asphalt tiles, and asphalt road surfacing (Virta, 2002).

Much of the decline in asbestos use in the United States was due to concerns over health risks posed by high-level exposures to airborne asbestos fibers. Beginning in the 1970s, public pressure to reduce asbestos use helped spur the quest for alternatives. In addition, many companies ceased production of asbestos products mainly because of liability issues (Virta, 2005). As a result, U.S. consumption of asbestos declined from a peak of almost 660,000 $\mathrm{t}$ in 1976 to 4,650 $\mathrm{t}$ in 2003 (fig. 4).
The identification of health risks associated with longterm, high-level exposure to asbestos prompted regulations to limit the maximum exposure to airborne fibers in workplace environments. In addition, the spraying of asbestos insulation onto steel girders, consumer sales of raw asbestos, and artificial fireplace logs containing asbestos were banned. Commercial products such as asbestos-containing insulations, plasters, ceiling tiles, cement products, and caulks were slowly phased out (Virta, 2002).

In 1989, the EPA allowed the following asbestos end uses: asbestos-cement corrugated sheets, asbestos-cement flat sheets, asbestos-cement shingles, asbestos-cement pipes, asbestos clothing, automatic transmission components, brake blocks, clutch facings, disc brake pads, drum brake linings, friction materials, gaskets, millboard, nonroof and roof coatings, pipeline wrap, roofing felt, and vinyl-asbestos floor tile. In 2003, the main end use of asbestos was in roofing products where the asbestos is encapsulated in the asphalt.

Liability is a major issue for producers and manufacturers. This burden contributed to a shift by product manufacturers to asbestos substitutes, the redesigning of old products to eliminate the need for asbestos, or the designing of new products that require neither asbestos nor asbestos substitutes. In the United States, the use of substitutes has almost entirely replaced the use of asbestos (Virta, 2005).

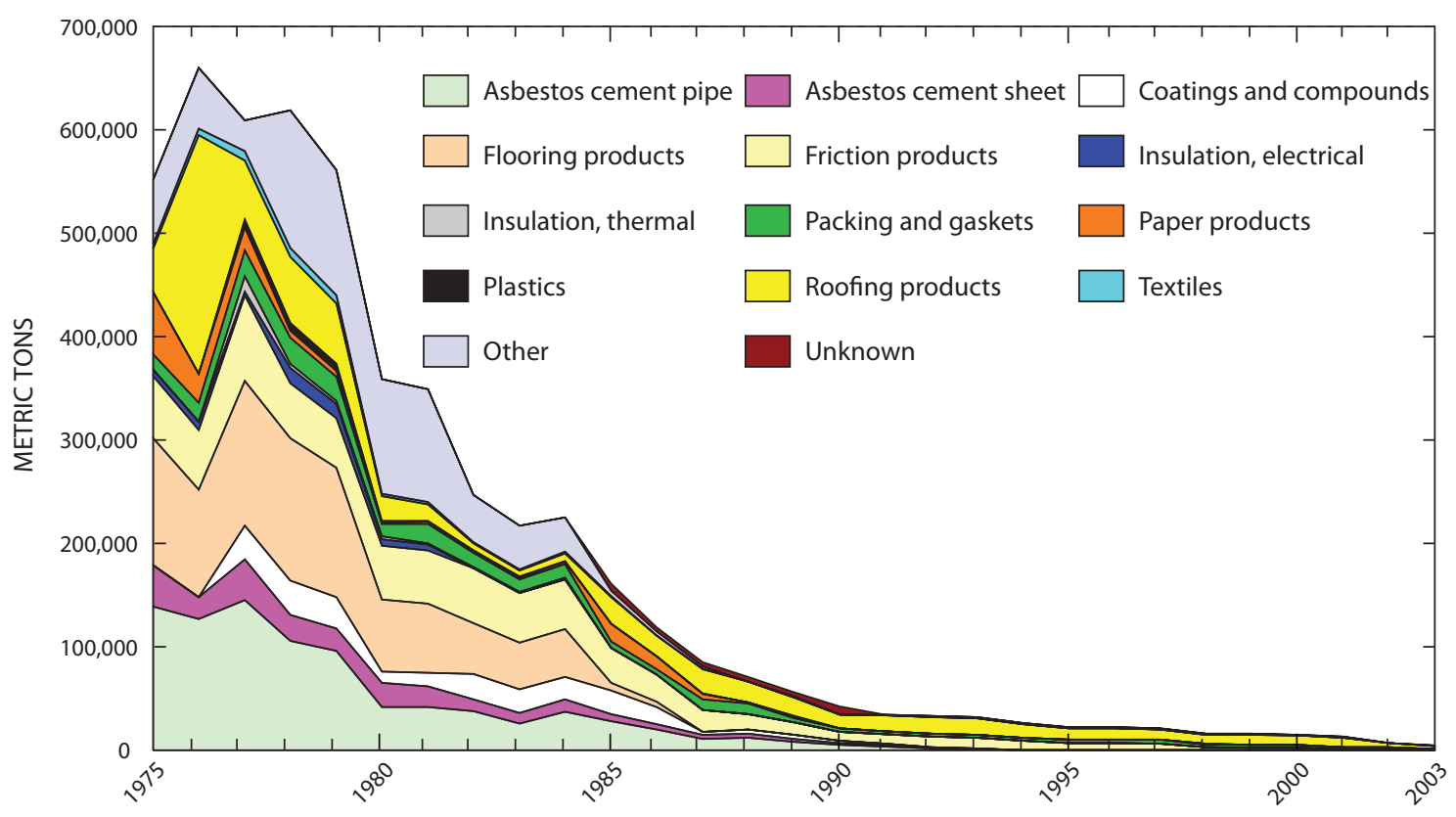

Figure 4. Asbestos end uses from 1975 through 2003 in the United States. 


\section{Lead}

Government programs continue to work to protect human health and the environment against the dangers of lead by conducting research, designing educational and outreach efforts, and developing regulations. Laws and regulations have been put into place to address the health and environmental issues in the United States. For example, the EPA promulgated rules that limit the use of lead in gasoline, reduce lead in drinking water, reduce lead in industrial air pollution, and ban or limit lead used in consumer products, including residential paint.

Lead is a widely used metal. It was used as an additive to gasoline to enhance engine performance until 1973. A negative consequence of this application was the emission of harmful lead compounds into the atmosphere as a component in exhaust. In 1973, the EPA issued standards that called for a gradual decrease in the use of lead to reduce the health risks from automobile exhaust. In 1986, the EPA announced standards to reduce the amount of lead used in gasoline by an additional 90 percent; and finally, on January 1, 1996, the EPA issued a direct final rule (40 CFR Part 80) that prohibited the use of lead in gasoline additives for highway vehicles (U.S. Environmental Protection Agency, 1996). This ruling resulted in the reduction of lead consumption in gasoline from almost $189,000 \mathrm{t}$ in 1975 to zero in 1995.

Lead use trended upward for most of the time period of this analysis (1975-2003) (fig. 5). Lead use in gasoline additives was eliminated, but the use of lead in recyclable lead-acid storage batteries increased. Lead use rose from 1 million t per year in 1975 to 1.4 million $t$ in 2003 , with the highest peak of nearly 1.8 million t in the year 2000, primarily because of an increase in the use of lead-acid storage batteries. Lead use in the production of batteries increased from about 60 percent of total lead used in the United States in 1975 to 81 percent in 2003. The most common use of lead-acid batteries is to start cars and other internal combustion vehicles. Lead-acid batteries also are used to power electric vehicle motors, and to provide emergency power when the commercial electricity supply is disrupted, mostly for computer and telecommunication systems. Recent research by Wilburn and Buckingham (2006) indicates that total lead use in the United States is greater than reported U.S. apparent consumption statistics when imports of lead-embedded manufactured products, like batteries, are factored in the consumption estimates. This approach may be significant in the estimation of apparent consumption of some commodities; however, measuring mineral consumption in products is complicated because it requires disaggregating the finished products into specific materials, which is a process that requires broad assumptions about the composition of the product.

The recovery of lead from spent lead-acid batteries and other lead scrap at secondary smelters in 2003 was sufficient to meet about 92 percent of the demand for lead in the manufacture of new batteries (Smith, 2003). The typical new lead-acid battery contains 60 to 80 percent-recycled lead and plastic. Almost any retailer that sells lead-acid batteries collects used batteries for recycling, as required by law in most States. When a spent battery is collected, it is sent to a permitted recycler where, under strict environmental regulations, the lead alloy, plastic, and other materials are reclaimed and sent to a manufacturer of new batteries. That means the lead and plastic in the lead-acid battery in your car, truck, boat, or

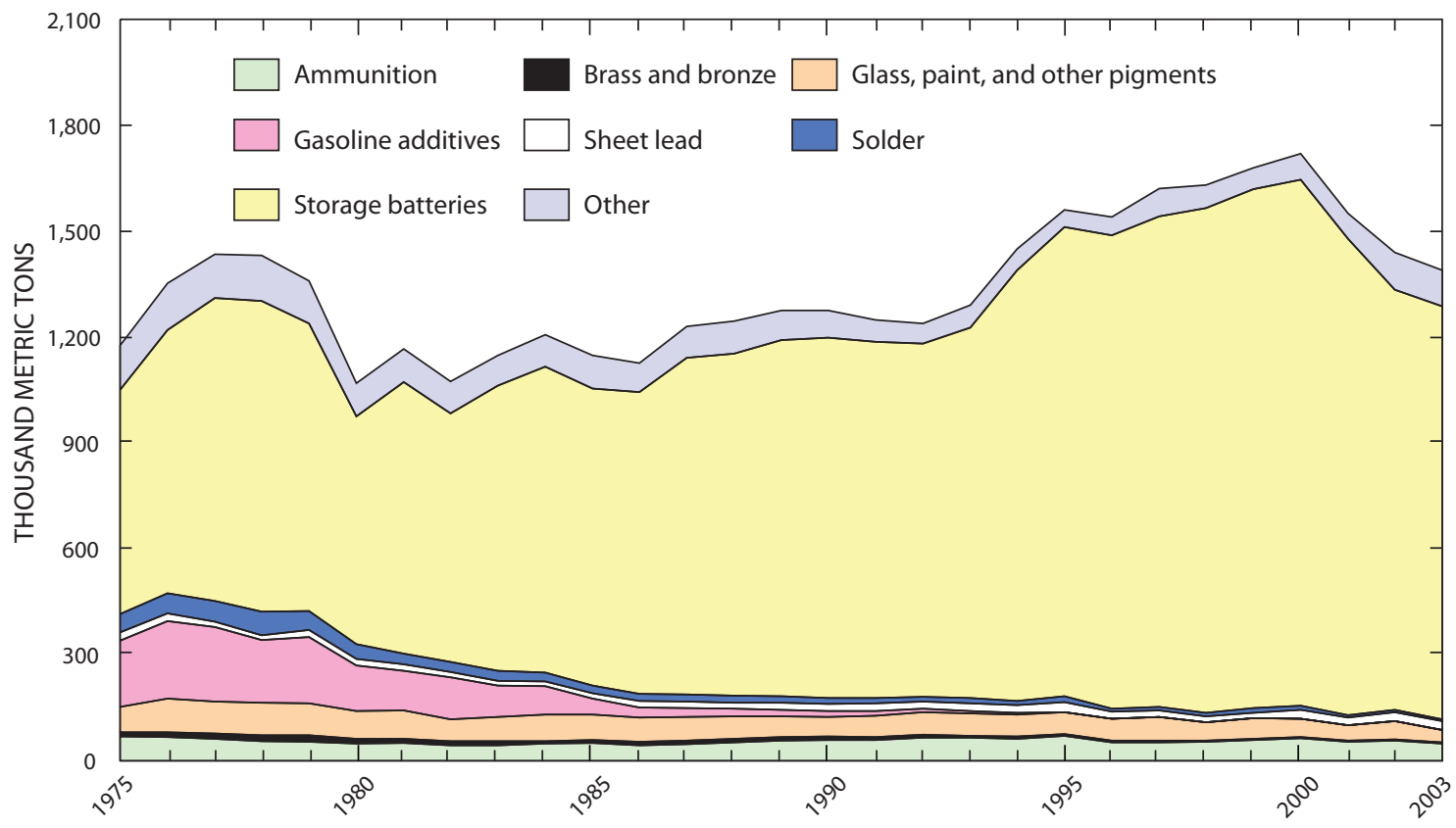

Figure 5. Lead end uses from 1975 through 2003 in the United States. 
motorcycle may have been - and may continue to be-recycled many times (Battery Council International, 2006).

Statistics for lead use in the "glass, paint, and other pigments" category are aggregated to avoid disclosing company proprietary data (fig. 5). Lead was added to paint as pigment and to speed drying, increase durability, retain a fresh appearance, and resist moisture, which caused corrosion. While the trend in this combined end-use category appears level, because of its toxicity, paint containing more than 0.06 percent lead was banned for residential use in 1978 by the U.S. Consumer Product Safety Commission. Paint with significant lead content is still used for commercial purposes in industry and by the military. For example, leaded paint is sometimes used to paint roadways, parking lot lines, and for artists' paint. The U.S. Consumer Product Safety Commission also banned toys and other children's products, such as playground equipment, bearing paint containing lead in excess of 0.06 percent by weight because these products pose a risk of lead poisoning in young children. Although lead improved the performance of paint, it is extremely toxic especially to children under age six whose bodies are still developing. In 1992, the U.S. Congress enacted the Residential Lead-Based Paint Hazard Reduction Act. Title $\mathrm{X}$ of that Act uses 0.5 percent lead by weight as the maximum allowed lead level in paint for lead hazard-control measures. This was designed to focus attention and resources on controlling the most significant lead paint hazards (U.S. Consumer Product Safety Commission, 1996). The use of lead in the glass, paint, and other pigments category has been maintained, primarily owing to lead being added to glass in televisions and computer monitors to protect users from radiation.

Much of the decline in nonbattery uses of lead was the result of the U.S. manufacturers' compliance with environmental regulations to reduce or eliminate the use of lead in products, including gasoline, paints, solders, and water systems. The amount of lead used in ammunition remained constant from 1975 to 2003.

\section{Mercury}

Federal, State, and local government agencies are concerned about the potentially toxic effects of mercury on the environment and human health. In the United States, the Resource Conservation and Recovery Act (RCRA) and the Comprehensive Environmental Response, Compensation, and Liability Act (CERCLA) mandate regulation of the production, use, generation, waste treatment, and disposal of products that contain mercury. Sznopek and Goonan (2000) developed a comprehensive timetable of mercury-related regulations at the Federal level that limited mercury use in the United States. In 1978, RCRA established regulations for disposal of mercury-bearing waste. In 1992, the EPA banned land disposal of wastes with high mercury content generated from chlor-alkali facilities. In 1993, the EPA canceled registrations of the last two mercury-containing fungicides at the manufacturer's request. In 1996, the Mercury-Containing and
Rechargeable Battery Management Act prohibited the sales of regulated batteries without recyclability or disposal labels and phased out most batteries containing mercury. Regulations and environmental standards relating to mercury use in products are likely to continue as major factors in limiting domestic mercury supply and demand. End-users of mercury-containing products may face fines and prosecution if these products are improperly recycled or not recycled. In the United States, several large companies and a number of smaller companies collect these products from a variety of sources, then reclaim, and recycle the mercury. Mercury reclamation from fabricated products has become the main domestic source of mercury; the commodity has not been mined as a principal product in the United States since 1992 (Brooks and Matos, 2005).

Mercury used in battery manufacture was the leading domestic end use of mercury until 1989 (fig. 6). The most common battery is the nonrechargeable alkaline primary battery. Before 1989, this battery type contained mercury in the insulating paper surrounding the battery to prevent the buildup of hydrogen gas in the canister of the battery, which could cause it to leak. (For the purpose of this paper, the categories of batteries, electrical lighting, and wiring devices were estimated from 1975 through 1978. During this time, the MYB grouped these categories in the electrical apparatus category.) Although the amount of mercury used in each of these batteries was small, the number of batteries sold in the United States was enough to make alkaline batteries the largest source of mercury in the municipal waste stream (Jasinski, 1994). The large number of batteries sold and disposed was attributed to the increasing numbers of consumer electronic items such as electronic games, portable radios, tape players, and toys. After 1988, mercury use in batteries decreased rapidly because of several States' regulations banning its use. Mercury used in batteries dropped from 55 percent of mercury use in 1985 to about 1 percent in 1994. In anticipation of the Mercury-Containing and Rechargeable Battery Management Act that became law on May 13, 1996, the use of mercury in the production of alkaline batteries was eliminated in the United States by 1995 . The purpose of this law was to ensure the phase out of mercury use in batteries and to provide for the efficient and cost-effective collection and recycling, or proper disposal, of used nickel cadmium batteries, small sealed leadacid batteries, and certain other batteries.

The manufacture of paint was the third largest use of mercury until 1989. In latex paint, mercury acted as a preservative to prevent the growth of bacteria during storage and as a fungicide to prevent mildew formation after use. In 1990, the EPA, in cooperation with the domestic paint industry, banned the use of mercury in interior latex paint. As a justification for the action, the EPA cited a risk of poisoning, especially in children, when using the paint in poorly ventilated areas (Jasinski, 1994). By 1991, mercury used in exterior paint was only $6 \mathrm{t}$; the use of mercury in all types of paint ended in the United States by 1992 .

Since 1989, the leading use of mercury in the United States has been in the manufacture of chlorine and caustic 
soda (fig. 6). The manufacturing process in the chlor-alkali plants created waste that was landfilled domestically, shipped abroad as industrial waste, accumulated within pipes in the plant, or lost through evaporation creating pollution. After 1992, the EPA ban on land disposal of high mercury-bearing waste required chlor-alkali plants to construct onsite treatment facilities, or ship their waste material to be processed elsewhere. The use of mercury by the chlor-alkali facilities declined owing to the closing of a number of plants using the mercury cell process, the development of nonmercury technologies, and the increasing concern over human health and the environment (Brooks and Matos, 2005).

Mercury used in wiring devices and switches in older cars, fluorescent lamps ("electrical lighting" on figure 6), and thermostats ("measuring and control devices" on figure 6) is of environmental concern because of the potential for mercury releases during demolition, scrapping, and waste treatment. More detailed information on usage than is currently available is necessary to understand the use of mercury and its effects on people and the environment. Additionally, the amounts of mercury incorporated into the economy are significant because imports of finished products containing mercury are not included in the end-use statistics, but are relevant for the characterization of the total U.S. mercury use and disposal of these products.

\section{Shifts in End Uses of Mineral Commodities Owing to Changing Technologies}

One complex societal challenge is reduce environmental degradation while maintaining or increasing services from mineral materials and products. Understanding how the applications of technologies affect the use of mineral commodities is a key element in reducing contamination and conserving resources. The following commodities were selected for the analysis of the end-use shifts resulting from the emergence of new technologies: gallium, germanium, indium, and strontium. These new technologies either created new applications for these mineral commodities in products, or eliminated the need for the commodity in some products.

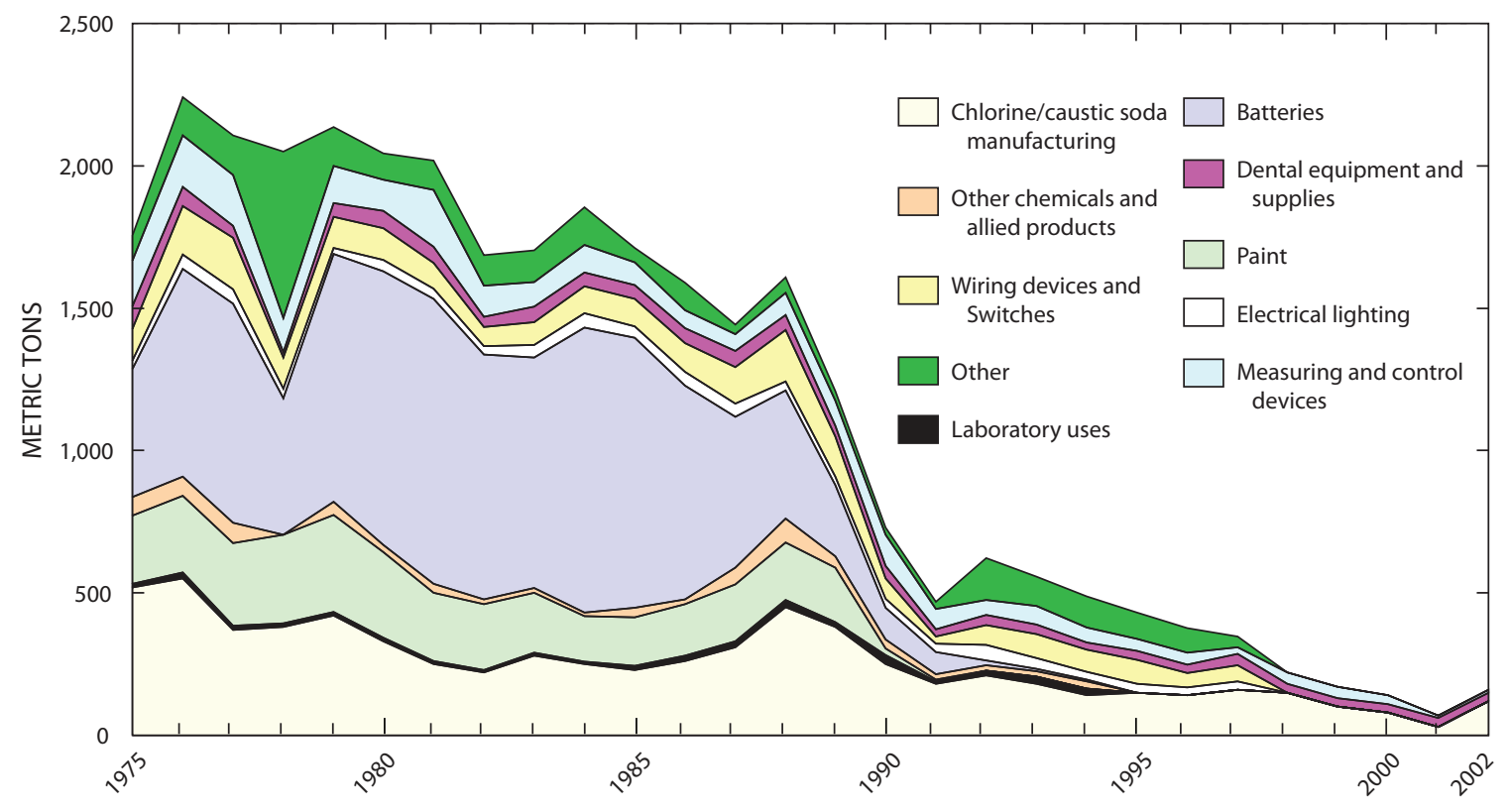

Figure 6. Mercury end uses from 1975 through 2002 in the United States. 


\section{Gallium}

New technologies allow for new uses for gallium owing to its properties of conductivity, transparency, and resistance to high temperatures. Gallium also easily alloys with most metals. Analog integrated circuits (IC) are the most common application for gallium, with optoelectronic devices (mostly laser diodes, light-emitting diodes [LEDs], photodetectors, and solar cells) as the second largest end use. Gallium has semiconductor properties, especially as gallium arsenide (GaAs), which can convert electricity to light for use in LEDs for electronic displays. Increasing sales of electrical and electronic products have increased the use of gallium. ICs are used in defense applications, high-performance computers, and telecommunications equipment. The other major end use, optoelectronic devices, is used in aerospace, consumer goods, industrial equipment, medical equipment, and telecommunications (Kramer, 2006).

LEDs remain in widespread use for many electronic displays, owing to its characteristic of producing brighter and longer lasting lights. New applications for GaAs are in automotive lighting, cellular telephones, backlighting for liquid crystal displays and television monitors, entertainment and decorative lighting, and signage. GaAs-based laser diodes were used in such items as compact disks and digital videodisk players, and GaAs-based ICs are used in sophisticated military radars (Kramer, 2004).

Gallium consumption rose 168 percent from 1975 to 2003. Most noticeable was the growth in the overall amount of gallium used in the production of IC which grew from $3.15 \mathrm{t}$ in 1988 to $8.14 \mathrm{t}$ in 2003 , reaching a peak 2000 of $26 \mathrm{t}$ or nearly 66 percent of total gallium use. Consumption of gallium in optoelectronic devices reached a peak in 1995 of nearly 88 percent of total gallium use (14.80 t). In 2000, the apparent consumption of gallium, most of which was imported in raw mineral form from China, Japan, and Ukraine, reached a peak of nearly $40 \mathrm{t}$. The precipitous drop in gallium use after 2000 probably is attributable to the off-shoring of a significant portion of the GaAs-wafer manufacturing capacity to other countries, such as China, the Republic of Korea, and Taiwan. Gallium metal imports, therefore, were not as large as they had been in previous years, which reduced the total U.S. apparent gallium consumption. The stagnant economy, especially in the wireless communications segment limited the use of gallium. In addition, manufacturers built up inventories of GaAs based on expectations of continuing demand and fears of a wafer shortage; this also contributed to a limited use of gallium metal (Kramer, 2002).

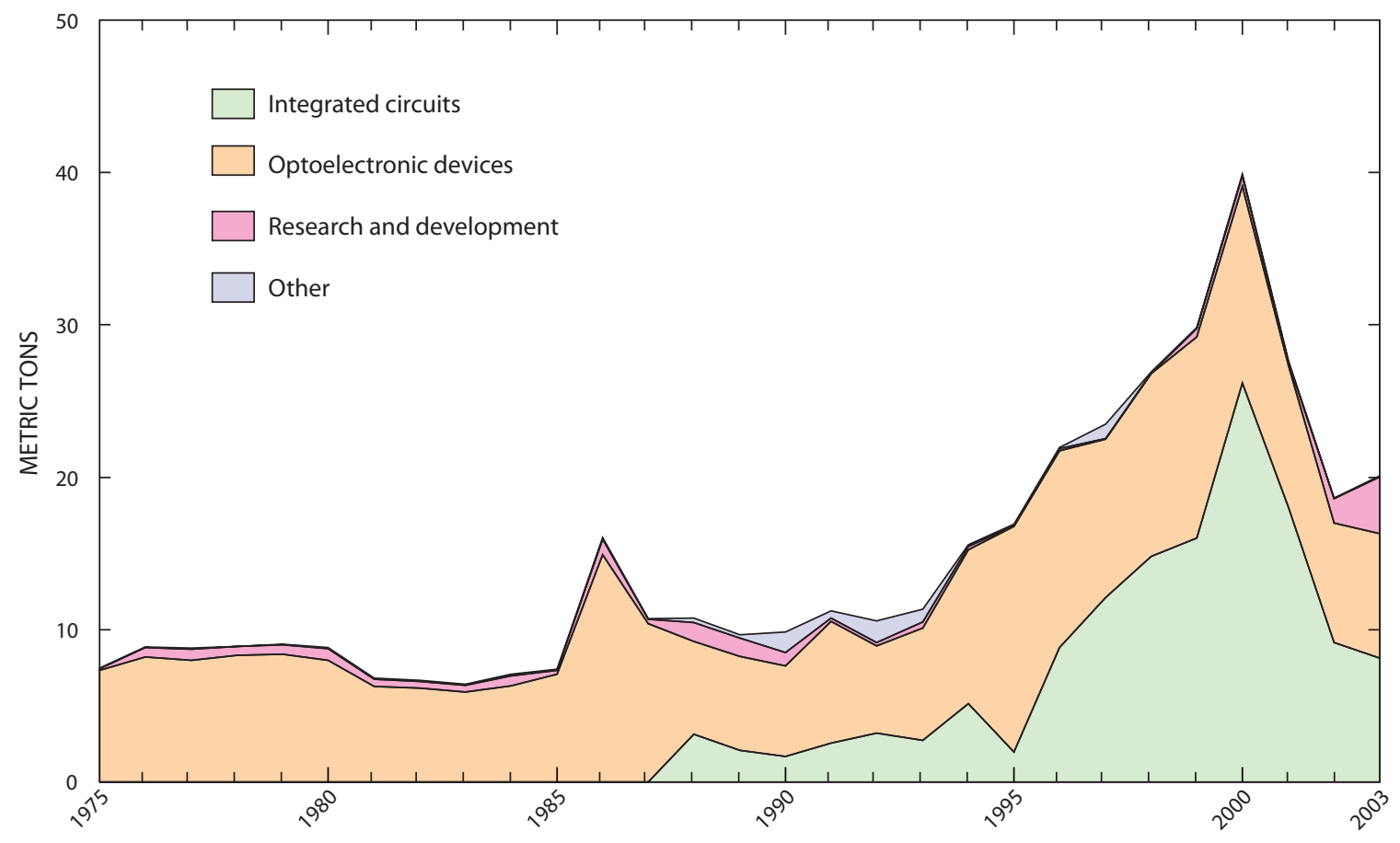

Figure 7. Gallium end uses from 1975 through 2003 in the United States. 


\section{Germanium}

Shifts in the patterns of germanium use in the United States provide a clear demonstration of advances of new technologies and applications that require the use of this mineral commodity. Germanium is an important semiconductor material with electrical and insulation properties. Unlike most semiconductors, germanium responds efficiently to infrared light; therefore, it is used in optical equipment that requires extremely sensitive infrared detectors.

These germanium-based optical systems have been used principally for defense applications, military guidance and weapon-sighting applications, including satellite systems and personnel detection equipment for poor visibility environments. Germanium optical glass also is used for nonmilitary purposes in monitoring systems and night-vision surveillance equipment. The ability to 'see' in the dark, or through fog or smoke, led to its widespread use by the military for weapons guidance and sighting (U.S. Bureau of Mines, 1980). Germanium usage in infrared systems increased sharply at the end of the 1970s, reaching a peak in 1988 of nearly 70 percent of U.S. apparent consumption (fig. 8). Then, a rapid downward trend in infrared devices occurred because, among other reasons, the radiation emitted from an active device makes it locatable (Butterman and Jorgenson, 2005). Nonmilitary applications of infrared devices have increased, but not enough to compensate for the decline of the use of germanium in military applications; therefore, the overall demand for germanium in the infrared systems category has decreased sharply since the late-1980s.
The expansion of the telecommunications industry in the 1990s required the use of germanium as a dopant, which is an impurity, added to silica glass to raise the index of refraction, in the manufacture of fiber optics. This end use expanded significantly in 2002 accounting for nearly 61 percent of U.S. germanium use (up from 8 percent in 1990). Until the 1980s, the trunk lines of telephone systems were made out of copper; by the end of the 20th century, nearly all copper lines had been replaced with fiber-optic lines (Butterman and Jorgenson, 2005).

In 1996, changes were made to the categorization of statistical data by the USGS. The use of germanium in semiconductor electronics in some of the radiation detectors was moved to the "electrical and solar panels" category. Concurrently, the use of germanium in "polymer catalysts" was separated from the "other" uses category. Germanium is used as a polycondensation catalyst for the late-stage polymerization of polyethylene terephthalate (PET), which is used in plastic bottles, films, food packaging, and many other products (Jasinski, 2004).

In 2003, germanium use in fiber optics decreased substantially in the United States owing to the downturn of the telecommunications industry, the closures of several source (zinc) mines in Australia, Canada, and the United States, and the reduction of output of byproduct germanium in smelting facilities in Europe (Jasinski, 2004). Both worldand domestic-use patterns decreased because of the strong downturn in telecommunications. After 2003, the United States no longer used germanium in polymerization catalysts. Germanium contained in imported products is not accounted for by domestic statistics.

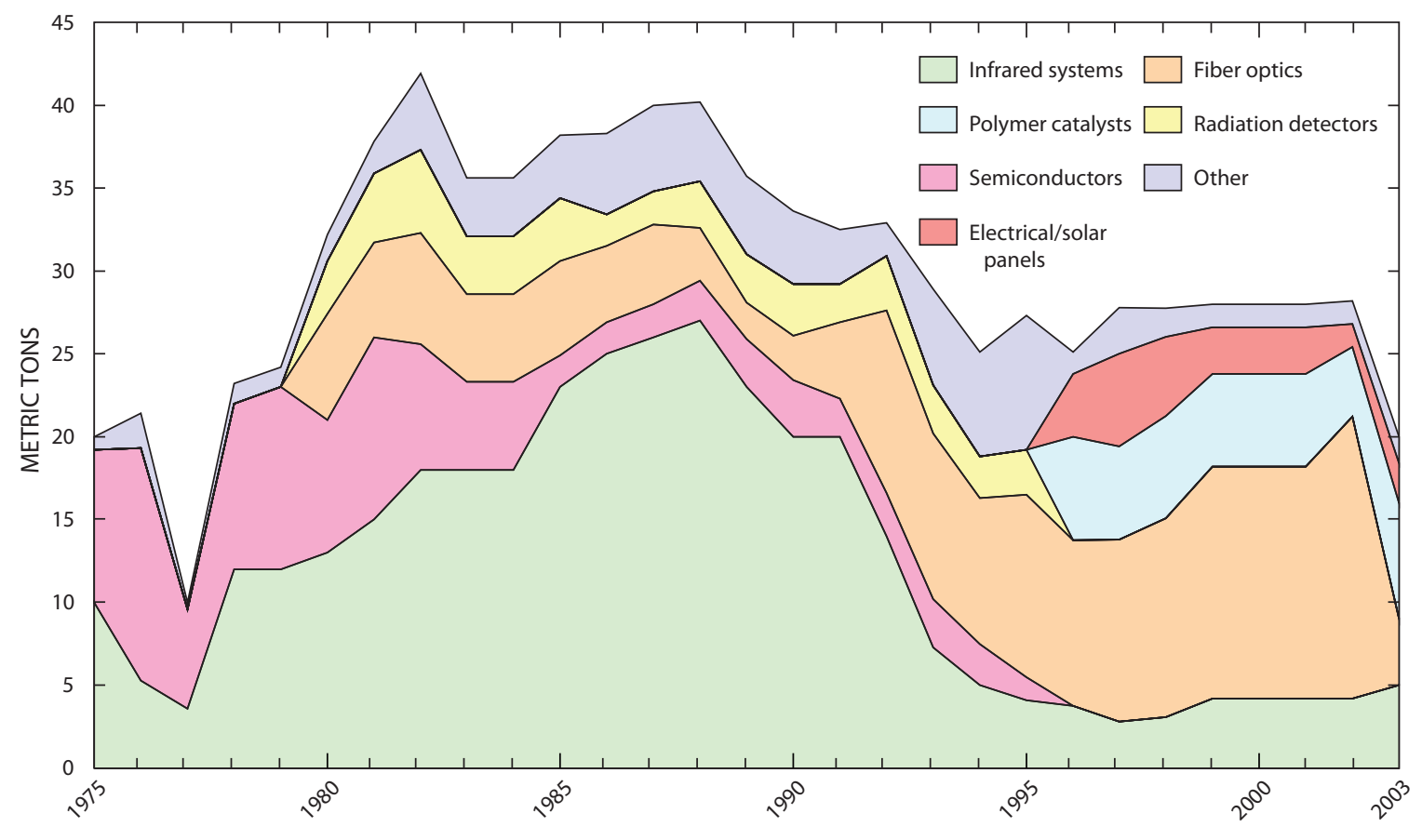

Figure 8. Germanium end uses from 1975 through 2003 in the United States. 
The use of germanium is expected to grow with a recovery of the telecommunications industry and the development of new technologies. Germanium is used in sterling alloy and in the thin-film application for DVDs (Jorgenson, 2002). The recent rise in energy costs has created a market for solar-panel applications. A possible new use for germanium that may change the future end-use pattern is the potential replacement of gallium arsenide by silicon-germanium ( $\mathrm{SiGe}$ ) in wireless telecommunication devices. $\mathrm{SiGe}$ is becoming an important semiconductor material for use in high speed IC. SiGe chips enable manufacturers to combine the high-speed properties of germanium with the low-cost, well-established production techniques of the silicon-chip industry (Gabby, 2006).

\section{Indium}

The first large-scale application for indium was as a coating for bearings in high-performance aircraft engines during World War II. Since then, technologies have been developed that require the use of indium, such as electrical components, semiconductors, solders, and alloys (fig. 9). The development of indium phosphide semiconductors and indium-tin-oxide (ITO) thin films for liquid-crystal displays (LCD) has shown strong growth in recent years. ITO is an essential component of plasma and LCD televisions as well as for computer monitors and many small LCD screens in mobile telephones and electronic devices, which have become mainstream products.

The coatings category is the leading indium end use. Two types of coatings contain indium-electronically-conductive and infrared-reflective. Indium on LCD for portable computer screens, television screens, video monitors, and watches are the major commercial applications for electronicallyconductive coatings. They also are used to defog aircraft and locomotive windshields and to keep glass doors on commercial refrigerators and freezers frost-free. Indium coatings on window glass use indium's infrared-reflective properties and limit the transfer of radiant heat through the glass. This property of indium is used to heat and cool buildings more efficiently (Carlin, 2004).

Indium use in the United States grew from $3.5 \mathrm{t}$ in 1975 to $90 \mathrm{t}$ in 2003, representing a total increase of nearly 2,500 percent. This increase reflects advancements of technology, especially in televisions, flat-panel displays, and other LCDs that use ITO coatings. Additionally, an increase in the size of monitors and television screens also contributed to the higher usage levels. The use of indium in coatings constituted nearly 66 percent of apparent consumption in 2003, up from 33 percent in 1975 .

Indium in the electrical components and semiconductors category was used in infrared detectors, high-speed transistors, and high-efficiency photovoltaic devices. Indium phosphide components can be substituted for GaAs in solar cells and many semiconductor applications, which could change the indium end-use pattern in the future (Carlin, 2006).

The analysis of the end-use data suggests the need to explore the potential recovery of indium contained in electronic appliances including LCD panels used in televisions and monitors, and mobile phones owing to the increasing preference for these products and the short supply of this commodity globally (Metal-Pages, 2006). Indium contained in these products is potentially toxic, therefore, recycling technologies are becoming increasingly important to deal with the environmental consequences of the final disposal of these products.

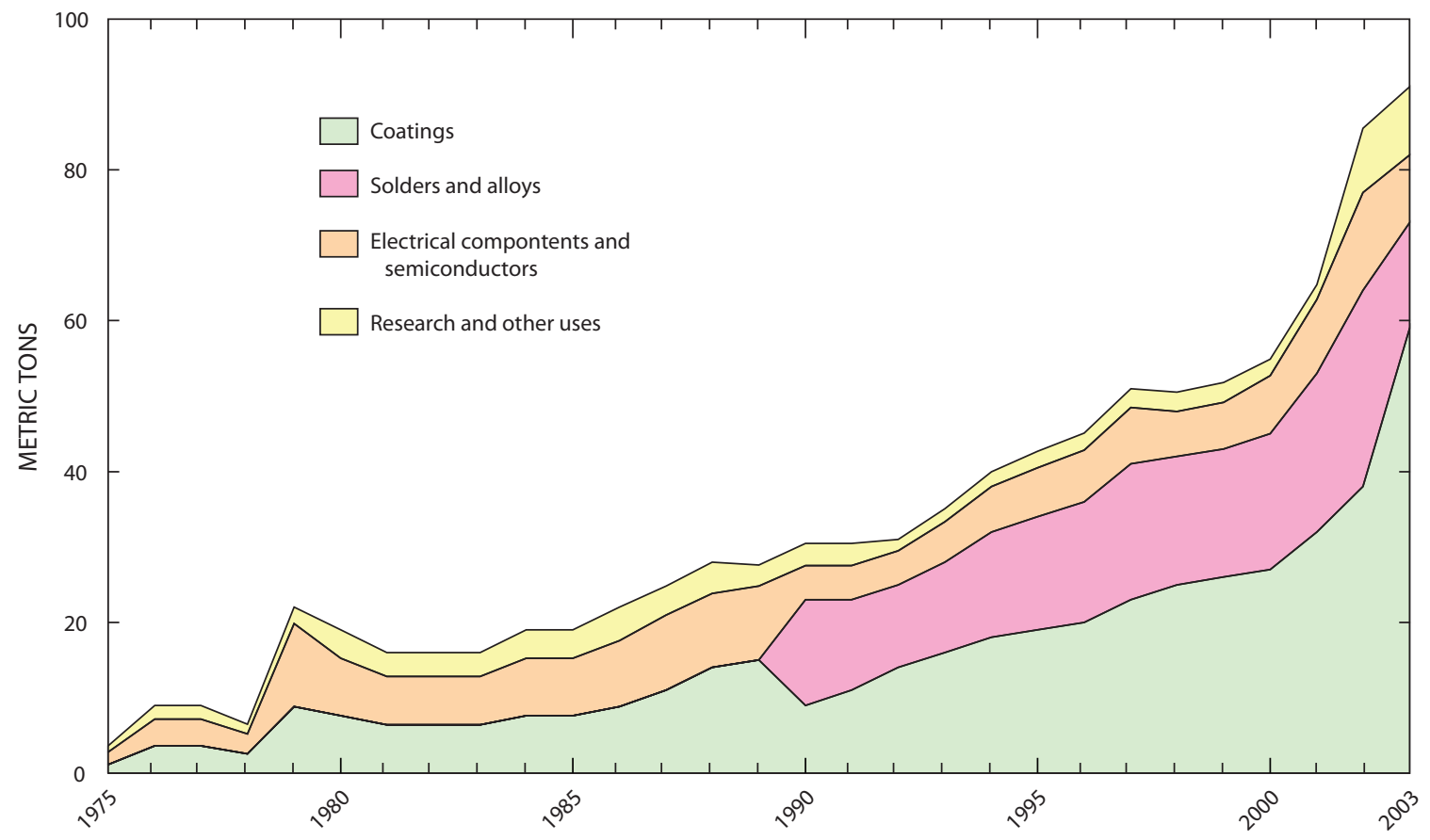

Figure 9. Indium end uses from 1975 through 2003 in the United States. 


\section{Strontium}

All color televisions and other devices that contain color cathode-ray tubes sold in the United States are required by law to contain strontium in the faceplate (glass) of the picture tube to block x-ray emissions. Major manufacturers of television picture-tube glass incorporate about 8 percent strontium oxide by weight, in the faceplate material. Strontium also improves the appearance of the glass and enhances the television picture quality (Ober, 2004).

As production of flat screens, which do not require strontium, continues to increase, the use of strontium will continue to decline (fig. 10). Strontium use in the United States generally increased until 1999, mainly owing to use in television picture tubes. Since then, overall use has declined with the shift to flat screens, and because color television faceplate glass production was shifting production from the
United States to Asia and Mexico. The end-use pattern of strontium shifted owing to technology no longer needing the use of this commodity for these applications. Strontium's leading end use, television picture tubes, reached a peak in 1999 at 28,200 t, representing 75 percent of total U.S. apparent consumption of strontium $(37,600 \mathrm{t})$. In spite of the decline, in 2003, the television picture-tubes application remained the predominant end use for strontium.

Other end uses consumed relatively small amounts of strontium and strontium compounds. Strontium titanate sometimes is used as a substrate material for semiconductors and in some optical and piezoelectric applications. Strontium chloride is used in toothpaste for temperature-sensitive teeth. Strontium phosphate is used in the manufacture of fluorescent lights, and the entire range of strontium chemicals is used in analytical chemistry laboratories (Ober, 2004).

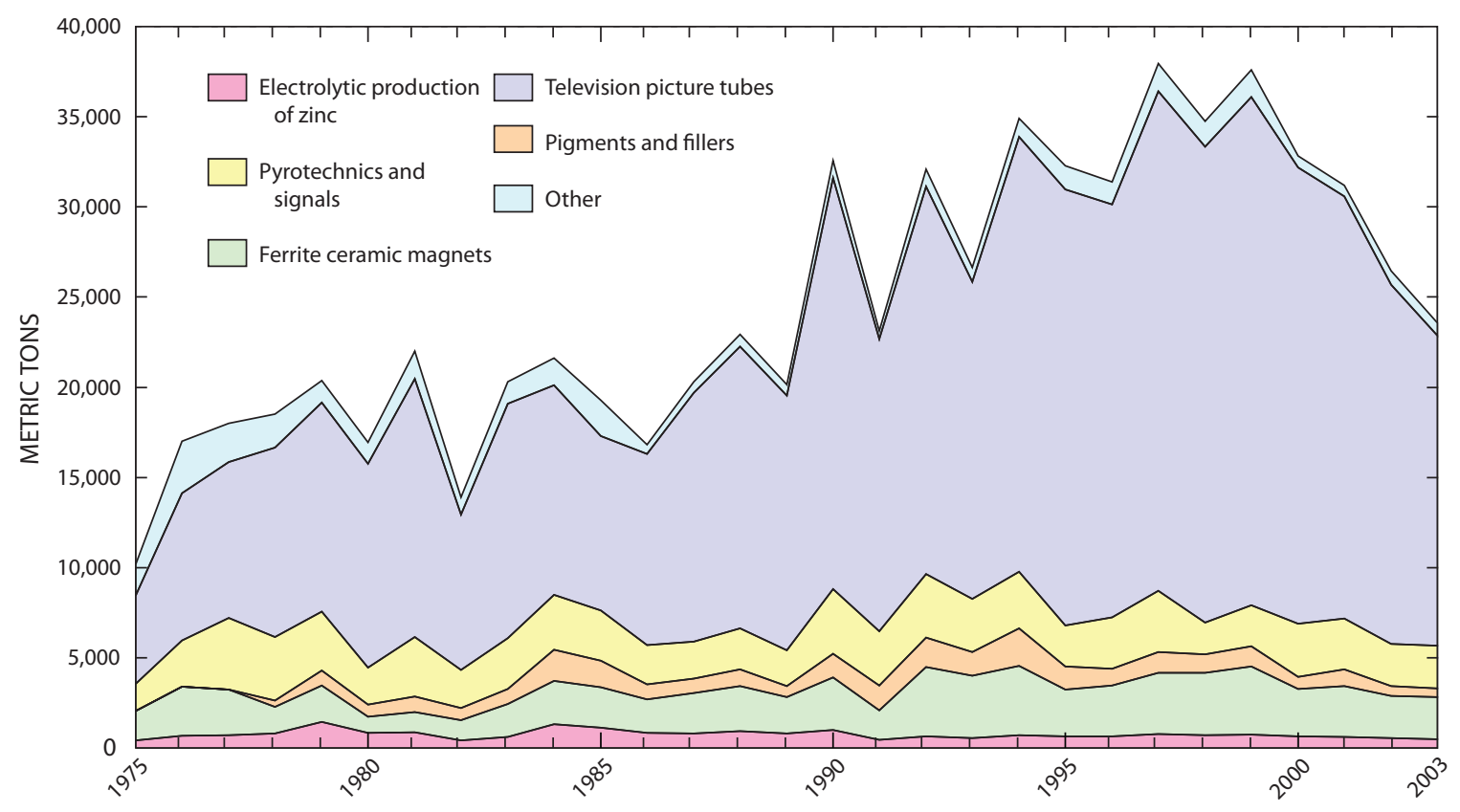

Figure 10. Strontium end uses from 1975 through 2003 in the United States. 


\section{Summary}

Several factors have contributed to changes in the use pattern of mineral commodities in the United States. The regulatory system and advancement of technologies are explored as factors that have been the drivers behind the end use in the eight selected commodities investigated in this report.

Awareness of the potentially negative environmental effects and concerns over public safety of some of the mineral commodities has resulted in regulation on the use of commodities like arsenic, asbestos, lead, and mercury. The level of arsenic use in agricultural chemicals, for example, shifted mainly because of several regulations enacted by the EPA that considerably reduced its use. The decline in this trend was counteracted by the increased use of arsenic in wood preservatives, which uphold the amount of the overall arsenic use in the United States. The use of asbestos is tracked under rigorous regulated conditions. Health risks associated with high-level exposure to asbestos in workplace environments prompted regulations to limit the maximum exposure to airborne fibers. Because of public awareness of the negative effects on health and because of industry concerns for liability, several asbestos applications also were banned and domestic production closed down. The result was a sharp decline in asbestos use. The lead end-use pattern of consumption has been altered by the EPA which limited the use of lead in several products of dissipated use such as gasoline and paint to address issues associated with air pollution and public health, especially in children's ingestion of leaded paint chips. While lead use in gasoline additives decreased, lead used in storage batteries increased, becoming one of the success stories of recycling, due to law requirements in most States. Environmental regulations in the United States, the Resource Conservation and Recovery Act, and the Comprehensive Environmental Response, Compensation, and Liability Act regulate mercury generation, waste treatment, use, and disposal of mercury-containing products. End-users of these products may face fines and prosecution if the products are improperly recycled or not recycled. The manufacture of mercury-containing products like batteries, paint, and electrical and electronic instruments are eliminated in the United States; however, the products are still flowing into the economy through imports.

Advancements in technology and demand for new products have shifted the end-use pattern of selected commodities like gallium, germanium, indium, and strontium in the United States. The expansion of the telecommunications industry and increasing demand for electrical and electronic products, which have become mainstream products, require the use of these mineral materials. Gallium consumption, for example, increased in 168 percent from 1975 to 2003. The expansion of the telecommunications industry which requires integrated circuits, and the increasing sales of electrical and electronic products that use light-emitting diodes displays were the strong force behind the upward trend in gallium consumption. Germanium was used mainly for military applications. The germanium contained in infrared systems was used in optical equipments and extremely sensitive infrared detectors until the late 1980s, when this application dropped sharply. Subsequently, the expansion of the telecommunications industry and development of technology found new applications for germanium in fiber optics. Indium use grew substantially from 1975 to 2003; new technologies have been developed that require the use of indium in electrical components, semiconductors, and a variety of alloys. Indium is an essential component of plasma and LCD televisions as well as for computer monitors and many small LCD screens in mobile telephones and electronic devices, which have become mainstream products. To deal with the environmental consequences of the final disposal of these products, recycling technology is becoming more important. Finally, strontium illustrates a case where technology and industry preferences no longer need the use of this commodity for the color cathode-ray tubes included in televisions and other devices. The strontium use in television picture tubes is declining as the preference for flat-screen panels and computer monitors has increased.

In general, information on the end use of a mineral commodity provides an overview of the flow of that commodity through the economy and an indication of how the mineral commodity is used over time. Detailed analysis of end-use trends can be a valuable tool for understanding the quantities and types of materials used, and for gaining insights into future use. This information is helpful for understanding the magnitude and character of these flows, assessing their effects on the environment, and providing an early warning of potential problems.

End-use analysis informs the public and decision makers of possible issues regarding the final disposition of products containing the mineral commodity, the subsequent implications for waste management, and where possible recycling opportunities for the mineral commodity may take place. The USGS plays a vital role in this effort by collecting and analyzing mineral commodity data. 


\section{References Cited}

Battery Council International, 2006, Battery recycling: Battery Council International, accessed March 24, 2006, at http:// www.batterycouncil.org/recycling.html

Brooks, W.E., and Matos, G.R., 2005, Mercury recycling in the United States in 2000, in Sibley, S.F., comp., Flow studies for recycling metal commodities in the United States: U.S. Geological Survey Circular 1196-U, 21 p, accessed October 19, 2006, at http://pubs.usgs.gov/circ/c1196u/

Busse, J.P., 2004, Survey methods for nonfuel minerals, in Metals and minerals: U.S. Geological Survey Minerals Yearbook 2002, v. I, p. 1.1-1.3, accessed October 20, 2006, at http://minerals.usgs.gov/minerals/pubs/commodity/ survey_methods/survemyb04.pdf

Butterman, W.C., and Jorgenson, J.D., 2005, Mineral commodity profiles-Germanium: U.S. Geological Survey Open-File Report 2004-1218, 19 p., accessed February 8, 2006, at http://pubs.usgs.gov/of/2004/1218/

Carlin, J.F., Jr., 2004, Indium, in Metals and minerals: U.S. Geological Survey Minerals Yearbook 2002, v. I, p. 36.136.5, accessed October 20, 2006, at http://minerals.usgs. gov/minerals/pubs/commodity/indium/indiumyb04.pdf

Carlin, J.F., Jr., 2006, Indium: U.S. Geological Survey Mineral Commodity Summaries 2006, p. 82-83, accessed October 20, 2006, at http://minerals.usgs.gov/minerals/pubs/ commodity/indium/indiumcs06.pdf

Cornell University, 1993, Inorganic arsenicals; conclusion of special review 11/93: Cornell University, accessed July 12, 2006, at http://pmep.cce.cornell.edu/profiles/miscpesticides/ alphaalkyl-metaldehyde/inorganic-arsenicals/in-arsenicalsp-rev.html

Gabby, P.N., 2006, Germanium: U.S. Geological Survey Mineral Commodity Summaries 2006, p. 72-73, accessed October 20, 2006, at http://minerals.usgs.gov/minerals/ pubs/commodity/germanium/germamcs06.pdf

Industrial Minerals, 2005, Applications of nano-sized materials: Industrial Minerals, no. 448, p. 47.

Jasinski, S.M., 1994, The materials flow of mercury in the United States: U.S. Bureau of Mines Information Circular 9412, 28 p., accessed October 20, 2006, at http://pubs.usgs. gov/usbmic/ic-9412/

Jasinski, S.M., 2004, Germanium, in Metals and minerals: U.S. Geological Survey Minerals Yearbook 2002, v. I, p. 31.1-31.4, accessed October 24, 2006, at http:// minerals.usgs.gov/minerals/pubs/commodity/germanium/ germamyb04.pdf
Jorgenson, J.D., 2002, Germanium, in Metals and minerals: U.S. Geological Survey Minerals Yearbook 2000, v. I, p. 32.1-32.5, accessed October 24, 2006, at http://minerals. usgs.gov/minerals/pubs/commodity/germanium/germmyb02. $p d f$

Kelly, Thomas, and Matos, Grecia, comps., 2005, Historical statistics for mineral and material commodities in the United States (ver. 1.0): U.S. Geological Survey Data Series 2005-140, accessed September 26, 2006, at http://minerals. usgs.gov/ds/2005/140/

Kramer, D.A., 2002, Gallium, in Metals and minerals: U.S. Geological Survey Minerals Yearbook 2000, v. I, p. 29.129.11, accessed October 24, 2006, at http://minerals.usgs. gov/minerals/pubs/commodity/gallium/gallmyb02.pdf

Kramer, D.A., 2004, Gallium, in Metals and minerals: U.S. Geological Survey Minerals Yearbook 2002, v. I, p. 28.128.15, accessed October 24, 2006, at http://minerals.usgs. gov/minerals/pubs/commodity/gallium/gallimyb04.pdf

Kramer, D.A., 2006, Gallium: U.S. Geological Survey Mineral Commodity Summaries 2006, p. 66-67, accessed October 24, 2006, at http://minerals.usgs.gov/minerals/pubs/ commodity/gallium/gallimcs06.pdf

Matos, G.R., and Wagner, L.A., 1998, Consumption of materials in the United States, 1900-1995: Annual Review of Energy and the Environment 1998, v. 23, p. 107-122, accessed October 24, 2006, at http://pubs.usgs.gov/annrev/ ar-23-107/aerdocnew.pdf

Metal-Pages, 2006 (February 21), Japan to increase imports of electronic wastes for recycling: Metal Pages Ltd., accessed March 29, 2006, at http://metal-pages.com

Ober, J.A., 2004, Strontium, in Metals and minerals: U.S. Geological Survey Minerals Yearbook 2002, v. I, p. 73.173.9, accessed October 24, 2006, at http://minerals.usgs. gov/minerals/pubs/commodity/strontium/stronmyb04.pdf

The Silver Institute, 2005, Silver ions in house frames helps resist mold and mildew, in Silver News: The Silver Institute, p. 4, accessed November 23, 2005, at http://www. silverinstitute.org/news/3q05.pdf

Smith, G.R., 2003, Lead, in Metals and minerals: U.S. Geological Survey Minerals Yearbook 2001, v. I, p. 43.1-43.27, accessed October 25, 2006, at http://minerals.usgs.gov/ minerals/pubs/commodity/lead/lead_myb03.pdf

Sznopek, J.L., and Goonan, T.G., 2000, The materials flow of mercury in the economies of the United States and the world: U.S. Geological Survey Circular 1197, 28 p., accessed October 25, 2006, at http://pubs.usgs.gov/ circ/2000/c1197/ 
U.S. Bureau of Mines, 1980, Minor metals, in Metals and minerals: U.S. Bureau of Mines Minerals Yearbook 1980, v. I, p. 927-929, accessed October 25, 2006, at http://digicoll. library.wisc.edu/cgi-bin/EcoNatRes/EcoNatRes-idx?type= article \&did=ECONATRES.0056.0934.0075\&isize $=M$

U.S. Consumer Product Safety Commission, 1996, Consumer product safety review: U.S. Consumer Product Safety Commission, v. 1, no. 2, accessed May 4, 2006, at http://www. cpsc.gov/cpscpub/pubs/cpsr_nws02.pdf

U.S. Environmental Protection Agency, 1996, Prohibition on gasoline containing lead or lead additives for highway use: Federal Register, v. 61, no. 23, p. 3832-3838.

U.S. Environmental Protection Agency, 2005, Chromated copper arsenate: U.S. Environmental Protection Agency, accessed January 9, 2006, at http://www.epa.gov/oppad001/ reregistration/cca/
U.S. Interagency Working Group on Industrial Ecology, Materials, and Energy Flows, 1999, Materials report: U.S. Interagency Working Group on Industrial Ecology, Materials, and Energy Flows, Washington, D.C., 29 p.

Virta, R.L., 2002, Asbestos-Geology, mineralogy, mining, and uses: U.S. Geological Survey Open-File Report 2002-149, 28 p., accessed January 9, 2006, at http://pubs.usgs.gov/ of/2002/of02-149/

Virta, R.L., 2005, Mineral commodity profiles-Asbestos: U.S. Geological Survey Circular 1255-KK, 56 p., accessed January 9, 2006, at http://pubs.usgs.gov/circ/2005/1255/kk/

Wilburn, D.R., and Buckingham, D.A., 2006, Apparent consumption vs. total consumption-A lead-acid battery case study: U.S. Geological Survey Scientific Investigations Report 2006-5155, 9 p., accessed January 9, 2007, at http://pubs.usgs.gov/sir/2006/5155/ 
